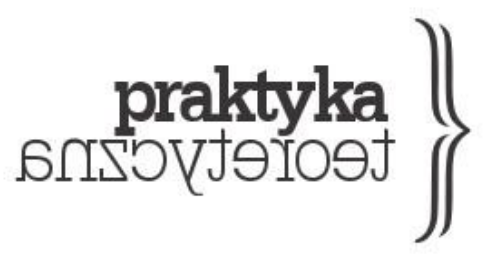

ISSN 2081-8130

DOI: $10.14746 /$ prt.2018.1.7 www.praktykateoretyczna.pl

\title{
COMMONING IN THE DIGITAL ERA: PLATFORM COOPERATIVISM AS A COUNTER TO COGNITIVE CAPITALISM
}

\author{
JAN J. ZYGMUNTOWSKI
}

\begin{abstract}
With the widespread adoption of ICT technologies, platforms, social media and sharing economy businesses have emerged as models of economic organization. This paper examines their functioning on a micro level to provide a thorough critique. The theory of cognitive capitalism and opposing arguments are explored in order to bring a holistic understanding and observe how value is captured and accumulated with the use of technological apparatuses. Cognitive capitalism is not uniform, however, and recognition of the special properties displayed by networks makes it possible to identify the challenge posed by the rising array of netarchist platforms. Platform cooperativism is the proposed egalitarian and long-term sustainable counter, as it aims to design new tools in line with the commons paradigm. Finally, the paper provides key insights into the specifications, difficulties, and next steps required to lead to better platform co-ops and a better future.
\end{abstract}

Keywords: platform cooperativism, cognitive capitalism, sharing economy, value, digital commons. 
Our product is so superior to the status quo that if we give people the opportunity to see it or try it, in any place in the world where government has to be at least somewhat responsive to the people, they will demand it and defend its right to exist.

"Travis law", coined by Travis Kalanick, Uber ex-CEO

Undoubtedly, the capitalist economy is going through a fascinating and overarching transformation, in greatest part as a result of the widespread adoption of ICT (information and communication technologies) and the massive accumulation of financial capital. Both phenomena will soon have been dominant for half a century in total. But more recently completely new schemes of commodity production and consumption systems have emerged with the rise of digital platforms.

Multi-sided platforms - the prime example of business models in the digital era combine the elegance of smartphone apps with the corporate power of organizing. They collect, store, and catalogue data, allow a variety of sides participate in exchanges and service provision, cater to the requirements of comfort, and enable rapid and secure access to their virtual infrastructure. It is possible to observe the emergence of a new megastructure of reality that runs through the physical, analogue world, but that retains a meta-level thanks to its information-based, cognitive quality (Bratton 2016).

It is crucial to remember, however, that the appearance of new technologies and the details of their deployment are not exogenous. They are a result of specific strategies of research and implementation, to some extent in keeping with the will of capital. A striking concept envisioning such a future was Jeremy Rifkin's The Age of Access, in which a world is described where every piece of reality has been privatized, commoditized, and monetized (Ryfkin 2000). Industrial production will lose in significance and accordingly in price compared to immaterial assets - knowledge, music, images, and ultimately even ideas and network access itself. Capturing this value is key to the power of the new dominant classes.

But is this not, and increasingly so, the reality already faced throughout the world? And is it the only reality possible?

This article is an attempt to critically analyze the micro- and macro-economic sides of the corporate model of digital platform. It sums up the great body of journalistic work that appears in public debate often, yet is still lacking in its formal grounding in economic literature. This practical part leads directly to a system-level discussion on cognitive capitalism as the new mode of capital accumulation superseding industrial capitalism. 
Whether cognitive capitalism is truly the prevalent mode now is an empirical question. Here I argue that most of the counter arguments to the cognitive capitalism viewpoint expressed around the dot-com bubble have been invalidated by new developments concerning digital labor and immaterial assets. It is therefore assumed for the purpose of this article that cognitive capitalism has indeed become, even if spatially it is still relatively restricted, the primary scheme for financial capital. Cognitive capitalism is furthermore explored to define how digital networks function in its regime and what the specific conditions are regarding netarchical platforms.

Cognitive capitalism is evolving toward its becoming a rentier state of apparatuses of value capture that control networks; but this evolution may well come to an end. Interest in the theory of commons has been flourishing recently, even finding its way into less theoretical debates. The rising popularity of "platform cooperativism," a term coined by Trebor Scholz to describe successful applications to, and emerging theory about, the new praxis of digital resistance, points the way forward for a modern social economy. Egalitarian ownership and democratic practice among cooperatives are indeed possible on a global scale given the development of communications technologies. Lastly, I argue that, while multistakeholder platform co-ops have their downsides, they are the most viable counter to cognitive capitalism as we face it now.

\section{Critique of the corporate platform}

The digital-era economy gives rise to many new types of organizational vehicles located on different parts of the value chain. Such business models operate in a variety of ways, as cognitive work and information data can be commoditized and monetized on the market in manifold fashion, especially as key terms and ideologies are used to sustain public belief in their benevolent nature. Such was the growth of the sharing economy trend. Though based on healthy assumptions about tapping into the unused or underused value of assets, in contrast with the typically commercial exchange of services, usually by peer-to-peer networks, or about frictionless trade through the elimination of middlemen, the track record of many sharing economy companies proves how platforms willingly and successfully dive deep into the new regime of financial accumulation.

One of the most prominent examples is the case of Uber. As the largest representative of the sharing economy - its highest valuation reached 70 billion USD - Uber has managed to expand in the relatively typical sector of personal transportation. However, Uber's main claim was originally that it is an IT services company, thus releasing it from all 
regulatory responsibilities, ranging from workers' rights to antidiscrimination laws. In this way, Uber is a platform that determines prices, wages, deals with payments, reputation systems, and supply and demand distribution, and that operates outside existing regulations, purely on the claim of being a technological "disruption" (Zygmuntowski 2017). This status has enabled it to engage in unfettered operations, thus allowing Uber to capture the market and extract value while breaking competition rules and defeating any law-abiding business rivals.

Furthermore, it is far from the case that Uber reduces transaction costs to zero, something that sharing economy enthusiasts keep talking up. The company's margin keeps on increasing and is well above $1 / 4$ of a single drive price. On some local markets, Uber retains the low price model, especially if contested by other firms, while on others it has started to use its strong position to extract value. A flexible pricing strategy known as surge pricing $^{l}$ is also used to quickly boost profits from users in disadvantaged situations like terrorist attacks or poor weather conditions. Such an approach is defined by the realities of capitalism and the pressure of big capital, as investors who have spent years burning cash for Uber need a safe return on their investment and place great pressure on the firm.

Another widely recognized sharing-economy company that is causing negative spillovers is Airbnb. Many European and American cities have taken steps against the enterprise, from imposing fines and inspections to a complete ban on short-term rentals. High profits gained by landlords thanks to tourists have largely contributed to the process of gentrification of entire neighborhoods and blocks of flats. Rent raising and the unnatural growth of house prices in cities highly attractive to tourists, such as Paris, Barcelona, or New York, has led to a spoiling of the real estate market and a slump in the supply of available housing, which has impacted negatively on the quality of life of local residents and businesses (Lee 206).

A great variety of arguments address the problem of work instability and low labor protection standards, a problem that became widespread with the adoption of gig economy platforms. With self-employment and on-demand flexibility undermining the distinction between work and free time, and zero-hour contracts and other forms of employment pushing responsibility onto the "contractor," such work arrangements have been denounced many times. Some of those complaints have been upheld in courts - examples include the notable cases built against Uber and Lyft. This devaluation of labor and

\footnotetext{
1 "During times of high demand for rides, fares may increase to make sure those who need a ride can get one $[. .$.$] When you're online, your app displays areas with high demand for rides in shades of red. The deeper$ the shade of red, the greater that area's demand [...] Surge rates are charged as a multiplier of X.X. For example, a rider in a surging area may see and accept a surge multiplier of $1.3 \mathrm{x}$ or $2.1 \mathrm{x}$. This surge multiplier applies to the base, time, and distance of the trip fare." Source: https://help.uber.com/h/e9375d5e917b-4bc5-8142-23b89a440eec
} 
the commodification of workers themselves has even been referred to as Humans-as-a-Service (Kowalik 2017).

The concern over unclear platform policies also raises questions. Due to the technological advancement of the platforms, the precise architecture of system operations, data analysis, and information gathering, together with their influence on the presented services and products, or market access, remain largely unknown. Most of these platforms, whether part of the sharing economy, social media, or search engines, restrict access to their internal functions or clear paths with open APIs (Application Programming Interface) only for their own professional products (like ad management) or for selected partners - a business strategy rather than an attempt to pioneer transparency.

Not knowing has its consequences. Big data analysis may reinforce stereotypes and negative profiling by identifying correlation as causation (Crawford, Schultz 2014). Patterns, though, are often the visible end results of multivariable complex systems, which the algorithm sees as simple equations if so coded. Platforms may use their mechanisms to discreetly favour some groups or change the parameters of the market to maximize profit, even if it counters user experience. Some cases of tech profiling show extreme dangers - e.g., the Value-Added Model used for many years to assess teachers in the US showed clear inconsistency and had no accountability, yet it served its role by creating a proof-like outcome to explain significant job losses (O’Neil 2016).

In other situations, sharing economy platforms were able to reduce negative profiling, but choose not to. This was the case with Airbnb and its evident discrimination of African Americans (Edelman, Luca, Svirsky 2017). The findings from Fiverr and TaskRabbit - online freelance marketplaces - also show evidence of bias. Perceived user gender and race are significantly correlated with worker evaluations, which may harm the employment opportunities afforded to the workers (Hannák et al. 2017).

Arbitrary decision-making and lack of transparency may result in users accepting the mechanisms manipulating supply and demand sides, even though they would never accept them on traditional, analogue markets or if given more governance choices. However, very often the platforms or algorithms used are proprietary brands, and so their internal construction is considered a trade secret. Users are presented with a "black box," with little or no possibility of understanding, appeal, or co-governing (Pasquale 2016).

The very same critique applies to other kinds of platforms that remain outside the sharing economy paradigm. Retail websites, marketplaces, and social media as digital infrastructure operate in the same way. Whether Facebook, Instagram, or Alibaba, the methods used by such companies are profit-oriented and strictly hierarchical, even though they became socialized and common through practice (Fuchs 2013). 
Currently the observed growth of multi-sided platforms market is mainly being driven by positive network externalities, which are responsible for rising value if new users adopt the product (Katz, Shapiro 1985). It can be easily concluded that the optimal state is almost full concentration of the respective market, thus guaranteeing maximum supply and demand on all sides, and, as a consequence, more transactions and more data, which can fuel the further modeling of mechanisms and constant development of platform offers. Given such a situation, a company might consciously internalize negative network externalities, i.e., unwanted competition between supply providers, with specifically constructed algorithms, which diminishes the decrease in marginal positive network externalities growth (Li, Liu, Bandyopadhyay 2010).

Some academics believe that the possible negative consequences of strong market oligopolization will never occur, as low costs of change uphold competitive pressure on prices (Doligalski 2013). However, there is a scarcity of strong arguments supporting the idea that multihoming - the process of constant comparison and usage of different solutions will hold. One of the most specific characteristics of multi-sided platforms is their close to zero marginal cost per user, combined with their very low cost of market entrance (as per se entrance, not market capture). The optimal growth strategy, then, is to take part simultaneously in a technological and network building race.

Such competition is most likely to finish with a monopoly or at least an oligopoly, in which the market is no longer homogenous, due to the technologies used and the networks, which constitute different social groups. As a result the cost of change is substantial. We might observe this phenomenon in the technological heterogeneity (and accordingly social and cultural), and thus the cost of change, between Apple and Microsoft products, or membership on Facebook and vKontakte. More than accurate is the oligopolistic competition model of Reinhard Selten, in which demand relies not only on current prices, but to a large extent on the inertia of demand from previous periods (Selten 1968). The network externalities of digital platforms are many times stronger than in traditional, analogue business models and resemble rather the problems of natural monopolies.

We should also recall that platform users not only pay in the form of accepted monetary currency, but they also bring other values - their time and data. Every moment spent watching advertisements, on content co-creation or on providing service feedback is in fact a new payment. Private data constitute the highest form of intellectual property value, which allows for further technological refinement and control over the platform market, and through it the social and economic dimensions of the world (Ezrachi 2016).

Through these means platforms become "network rentiers," as Rachel O'Dwyer calls them (O’Dwyer 2015). The problem with rentier capitalism, which has been debated 
since the classical economy of Adam Smith and analyzed in-depth by Marxist economists, returns in the form of platform infrastructure, which abuses its monopolistic position to charge fees (even if, for a period of time, it may subsidize consumption to gain a foothold in the market). In the end, this amounts to a new process of primitive accumulation through enclosing common, public spaces - this time in artificially created, digital space - as a repetition of the often brutal and chaotic transition from feudalism to capitalism. David Harvey argues that the accumulation process continues wherever dispossession from public spaces and privatization of the commons takes place (Harvey 2005). Another theory is proposed by Hardt and Negri, who propose the two terms formal subsumption, which describes capital's drawing pre-existing labor relations into itself while taking control over means of production and compelling worker to wage-labor, and real subsumption, which characterizes capital's transforming and embedding all relations to comply with the profit-motive (Hardt, Negri 2017). ICT can be observed to influence both, although here it is formal subsumption that serves to explain how capitalism can pave its way to gain control over new fictitious commodities.

It seems justified to state that platforms seem to be attempts to enter and monopolize areas traditionally stewarded not only by the market, but also considered to be common, public and municipal goods. Many of the well-noted spillovers of platforms, such as ousting public transport, profit transfers, pressure on worker's rights, urban development, and other public-provided services, have gained the interest of global financial capital, which is constantly seeking new tools for economic extraction and social impact.

It is therefore crucial to observe digital multi-sided platforms as a product, as a tool of a bigger system. One of the most investor-acclaimed traits of platforms is their asset light model. The digital business model is the final step in full value chain decomposition, in which the platform takes place as a "meta" layer of the economy, where all the other participants clients, suppliers, producers, and analogue business partners - remain in the decision hierarchy but below the platform, even though they face most of the business responsibilities. Such observations have led Nick Srnicek to present a typology of platforms, which divides the landscape of the new infrastructure into five main categories:

1) advertizing platforms, which extract data from users, analyze it, and sell marketing services (e.g. Google, Facebook);

2) cloud platforms, which rent basic hardware and software to digital-dependent businesses (e.g. Amazon Web Services, Salesforce);

3) industrial platforms, which build internet-connected, smart manufacturing tools (e.g. GE, Siemens); 
4) product platforms, which capitalize on turning assets into stream of services, enabling rent collection (e.g. Rolls-Royce, Spotify);

5) lean platforms, which aims to reduce costs and liabilities to a minimum (e.g. Uber, Airbnb) (Srnicek 2016).

Out of the presented platform models, three of them - advertizing, cloud, and lean take almost exclusively the form of digital platforms. Product platforms can be of different types, depending on the type of good that is "streamed" (which may range from digital books and audio to patented formulas or even the brand itself), while industrial platforms bridge physical hardware with digital networks. It should be thought of as not only the muchanticipated Internet of Things and Industry 4.0, but also the power that Google and Apple hold with everyday smartphone operating systems (iOS, Android) and the keys to that power.

Platforms have to a large extent become a vehicle for international, unrestrained capital, motivated solely by profit and fueled by a specific culture formed in Silicon Valley. For venture capital funds, the platform is the ultimate form of the logic claiming that business is merely a revenue stream. The fewer the assets and operational activities, the more stable and easy-to-control the profit flows are. Financial means, processed via the black box of platforms and groups dedicated to them, should exit on the other side as ROI (Return on Investment). Little wonder then that in 2016 American VC funds invested almost 60 bln USD in new projects, most of which were platforms and marketplaces (Langley, Leyshon 2016).

\section{Production system of cognitive capitalism}

A close assessment of new digital ventures reveals extractionary goals, which are central to the functioning of these ventures. The rising influence of corporate digital platform companies largely contributes to the dismantling of social sustainability, welfare, and longterm maintenance. But in no way is their rise a sign of deviation from the proper workings of the market system - they are signs of the developmental continuity of capitalism itself.

The aim of this section is to provide theoretical underpinnings to the empirical problems found in the system comprised of corporate platforms. The literature on cognitive and netarchical capitalism provides conflicting models for understanding the modern economy, yet their synthesis brings some conclusions that are of extremely high relevance if any countermeasures to capitalism are to be proposed.

The socio-economic organization of production systems has been dynamically changing since the Taylorist model proved inadequate to new challenges. The increase and 
widespread adoption of the new ICT technologies has impacted the industrial paradigm, allowing for a transition into the postindustrial information age (Hutchinson 2008). The observed process is marked by a continually diminishing manual labor component in the economy organized around the production of physical goods, and a corresponding increase in the value and scope of a knowledge, information-based labor component that is organized around the provision of services. The postindustrial paradigm perceives knowledge as the most valuable factor in terms of productivity.

Numerous authors have argued with the "knowledge-based economy" hypothesis, the so-called "death of distance," and other postindustrial concepts that are so often eagerly used by business managers and analysts seeking to take advantage from participation in the reproduction of social relations and thus generate profit. The four main strands of the critique rely on the following arguments: that the Western perspective of high valueadded activities and robust capital intensity should not obscure the outsourced low-skill jobs and "traditional" capitalism operating in the rest of the world; that the great shift in capitalism leaves rather unremarkable signs on productivity factors; that worker mobility and connectedness on a global level is far from the proposed global, virtual workforce; and, finally, that the digital and networked Internet is embedded in capitalism and so only further extends its dynamics in all the spheres it touches (Huws 1999, Fisher 2010).

Whether that critique will continue to be valid is unclear, although some of the points made at the time of the dot-com bubble may now be defunct. Indeed, the global division of labor pushed manufacturing far from the line of sight of Western academia, yet the introduction of personal smartphones and further Internet expansion - from 5\% global user penetration in 1999 to $48 \%$ in 2017, and as much as $70.6 \%$ for young people (ITU 2017) - as well as the popular use of digital platforms, software, and codified knowledge in all types of business in every sector prove that manufacturing and even low value-added services as well are undergoing a critical change. Globalization is truly allowing the workforce to become worldwide, to the extent that the Global South is being forcibly drawn into digital workspaces, an example being the World Bank's program "m2work," which plugs hundreds of Palestinians in Gaza into the Amazon Mechanical Turk cognitive labor platform. It is crucial to understand the spatial limitations of capitalism, which has its own geographic dynamics. One might even argue that industrial capitalism took much longer to reach the edges of colonial agricultural powerhouses than cognitive capitalism has.

Finally, the debate as to whether ICT is just another technology embedded in existing capitalist social relations and its organization of production; or whether it marks a critical shift that changes the nature of the system, may miss the point. No technology is exogenous, although its deployment may entirely change the nature of a previous mode of production, which is what Hardt and Negri's real subsumption describes for the case of 
capitalist production (Hardt, Negri 2017). It seems indisputable that the famed "disruption" refers exactly to the process of creative, almost Schumpeterian destruction of previous modes of organizing the value chain and labor, just as we saw with electricity in the second industrial revolution. For those reasons, a sound theory of digital, cognitive, and netarchical capitalism is more relevant now than back when first hypotheses were formed, sometimes in a visionary, ahead-of-the-time manner.

The dynamic growth of new services and knowledge-based markets, born by the absorption of different artistic and creative activities as new types of wage labor, has met with attempts at definition and classification within the wider body of economic literature. Marxist Autonomists have proposed the term of "immaterial labor" to define how affective and cognitive states of humans are captured and monetized under the capitalist regime (Lazzarato, Negri 1991; Brouillette 2009). Current works on regimes of accumulation, and systems and models of production, which have transformed from Fordist and Taylorist times to our postindustrial era, have coined the phrase "cognitive capitalism" to mark the third stage of the capitalist system (Vercellone 2007).

Cognitive capitalism departs from neoclassical theories of the "knowledge-based economy," which support endogenous growth models, as well as from purely socio-technical analyses of civilizational development. The process of capital accumulation requires having control over and support for the transition from tacit to codified knowledge in order to commoditize it and extract possible value. Knowledge is useful insofar it produces a return on investments. However, cognitive capitalism draws on pre-existing conditions of knowledge production (Fumagalli, Lucarelli 2007). Mikołaj Ratajczak describes the following paradox:

Social antagonisms, such as the protest against privatizing the sectors necessary to produce "silent knowledge" (the institution of education), the codification of some knowledge types (DNA, personal data, etc.) and the imposition of proprietary relations on newer and newer forms of codified knowledge, arise against this backdrop. The production of social knowledge requires not only unrestrained access to codified knowledge, but also to the most basic resources of cognitive labor attention and time. The battle for those resources introduces a new type of antagonism: ways of measuring cognitive labor differ substantially from ways of measuring industrial labor. Social conflicts are born therefore both as a result of access restriction to codified knowledge (by intellectual property laws) and of attention resources (which are restricted by the costs of social reproduction) (Ratajczak 2015). 
The rise of new production models should be seen as a development of not only new possibilities for growth and freedom, but new methods of exploitation and capital accumulation as well (Vercellone 2007). Although emerging from welfare state and social policies aimed at easing the burden of industrial capitalism, cognitive capitalism undermines those very social relations. The prerequisites of this new form of accumulation are high $\mathrm{R} \& \mathrm{D}$ investments, and strong social and human capital. Private enterprises have come to benefit from the activities of the general intellect, while avoiding most of its related costs.

In the search for perfect investment opportunities, global financial capital now desists from directly investing in production processes, instead opting for the creation of apparatuses of value capture (Ratajczak 2015). It is no longer satisfactory to invest in production that generates income higher than costs. Under cognitive capitalism, the greatest return is not on wages and the means of production, but on vehicles that capture and extract value resulting from knowledge and information networks built on social reproduction. Extracted value is then rarely invested in production, so that the domination of accumulation typical of the regime of cognitive capitalism over the more stable, industrial, and analogue regimes is reinforced. This rent-seeking activity is limited not only to financial power, but occurs in governance and decision-making as well.

An important observation is that cognitive capitalism does not undermine the labor theory of value approach. Value creation and value extraction/capture are complementary processes, as the former describes the workers' side of the economy (no new value can be created without labor), whereas the latter depicts the ways in which capital obtains profit with new mechanisms. Intellectual property allows for the extraction of value through creative labor. There is nothing surprising other than that working conditions may still continue to deteriorate or that employment defiantly exists; cognitive capitalism focuses attention on new means of profit extraction, which turn from the ownership of physical capital to immaterial assets. At the same time, it describes the increasing exchange- and use-value of intellectual labor in the digital environment.

However, cognitive capitalism is not uniform, just as industrial production has its own value chains with some businesses operating in positions of stronger or weaker bargaining power concerning profits. Assessing the power of digital platforms, we might observe that what dominates in the new regime is network infrastructure, even though global companies founded on intellectual property laws (patents, unique software, etc.) have burgeoned in recent decades. That observation is consistent with other theories describing the current system of production. McKenzie Wark introduced the so-called vectoral thesis in A Hacker Manifesto, in which he claims that through the capture of attention and affection, the dominating vectoral class holds all the vectors of information (Wark 2004). Control over 
the means of communication, media, and platforms then makes it possible to reproduce the value of possessed intellectual assets, such as patents and brands.

But among the vectoralists, a booming sub-class exists that is even more powerful in terms of the magnitude and stability of their dominance. Michel Bauwens has proposed an alternative theory of netarchical capitalism, according to which the emerging class is constituted more by enablers and controllers of peer-to-peer, crowd-based, participatory, and co-creative networks (Kostakis, Bauwens 2014). Bauwens separates netarchists from all other cognitive capitalist agents, claiming that the peer-to-peer trait is more profound than vectoral control over information distribution or general knowledge assets capture. As he explains:

Compared to the cognitive capitalists and vectoralists, who respectively monopolize knowledge assets and information vectors, netarchists need neither one nor the other. Thus they do not necessarily side with the forces trying to rig computers with digital rights management restrictions, nor with the forces putting young people who share music in jail.

What Bauwens stresses here is that netarchists are immune to one of the two antagonisms that constitute cognitive capitalism. They still are subject to the social reproduction and attention limitations, yet they are not restrained with the need to produce knowledge assets protected by intellectual property laws. This leverage is enough to define their special status. The netarchical class resides on top of the new regime of accumulation, positioning itself at critical network nodes and acting as liquidity brokers in this, the data-driven era.

Netarchists and their platforms have been long seen as advocates of freedom and open access, though in fact this applies only to the freedom of passing through their domain, not to the exercise of its governance. As netarchists can never have full legal or economic certainty that their specific platform will remain popular and widely used in the future, they have to keep their users constantly engaged and feeling appreciated. This is the precise foundation of the co-creation and participatory model that many of those companies embrace, especially in the social media sector. An affective bond is a prerequisite of trust, much needed when profit-oriented strategies come into play.

Those theories should be seen as complementary rather than opposing. Certainly, cognitive capitalism, understood as a financial mode of production that creates tools of value capture and thus reinstates rents over information flows, is the most comprehensive theory for explaining not only the rise of digital platforms, but also the preceding shift from industrial labor to services and cognitive labor. Vectoralists herald the idea that intellectual assets are only as strong as the means of spreading them through key system nodes. 
In the end, the netarchical class is formed of a body of competing cognitive business models, which all aim to position themselves on top of the new, data-driven value chains. Multi-sided platforms do exactly that by controlling the information flows and networking possibilities between agents - whether they are freelance workers, industry production suppliers, or individuals exercising their spare time. All the new types of codified knowledge and collective value that are created as a result of network interactions can then be extracted in the form of pure rent by the platform owners as the sole governors of the node.

The dominant cognitive capitalist class and the digital infrastructure it operates can extract rent only if hackers, understood as programmers, creatives, and knowledge workers, create new apparatuses. As long as the social reproduction antagonism remains quite stable the labor market functions, industrial production continues, innovation and knowledge can be accessed, social or political unrest is below levels that would tear institutions apart - the key to dismantling cognitive capitalism lies in the hands of the hacker class. Just as new technologies allow for the creation of new apparatuses of value capture, so too may they be used for the purpose of shared, egalitarian governance, and a sustainable business ethics.

\section{The case for platform cooperativism}

The most recent evolution of cognitive capitalism sets the stage for a new type of conflict, one just as globalized as the basic premises of netarchical power. According to the theory of the dialectical double movement developed by Karl Polanyi, every process of commodification and marketization - insofar as it aims to dis-embed the economy from society and thus subordinate social relations to the market - is closely followed by a countermovement that seeks to protect the most marginalized groups and re-embed the economy (Polanyi 1944). This is the historical condition that has again arrived, as cognitive capitalism has reached its peak in the form of digital platforms and netarchical power.

However, new apparatuses of value capture are, in startup jargon, born global. Even though some resistance efforts on the part of unionized workers and cautious state administrations are undertaken locally, the solutions that prove themselves useful will need to be just as global as the most successful platforms - and this will mean utilizing network effects and driving innovation to stay on top of corporate-backed disruption. Platform cooperatives can be therefore seen as an attempt to present a full-fledged alternative that leads to mass emancipation (Mikołajewska-Zając, Rodak 2016). 
Platform cooperativism as a modern form of organic social struggle has been envisioned for some time. Various sources put forward a praxis of resistance through proprietary technology, one owned by the workers' themselves. It was the leading voice of Trebor Scholz of the New School for Social Research who coined the term "platform cooperativism." His widely cited, online article "Platform Cooperativism vs the Sharing Economy" has redefined the problem of the sharing economy and platform capitalism in general by offering a clear choice of return to the roots of collective organizing, while simultaneously fully embracing new technologies (Scholz 2014).

Scholz argues that the free participation of equal partners engaged in the production of common resources (in Bauwens' understanding), or networked peer production as a collective action carried out for distributed, non-market mechanism (in Benkler's understanding), can benefit from the traditions of cooperatives. The oft-cited example of Spanish Mondragon proves that cooperatives are not limited to some sectors only; their model displays high competitiveness and long-term sustainability as well, even when confronted with competition on purely market terms. The solidarity economy has proven in the past, and is continuing to do so in many places in the world, that a different model for organizing labor exists and that it is a viable alternative to corporate hierarchy.

The core premise of platform cooperativism, then, is to clone the "technological heart" of the new, digital platforms - social media, sharing economy, freelance websites, retail marketplaces and other types - while redesigning algorithms and the ownership structure so that they become transparent, democratic, and revenue-redistributive in their nature. Scholz believes that such platform co-ops are the panacea to the malaise of late cognitive capitalism:

\footnotetext{
Worker-owned cooperatives can offer an alternative model of social organization to address financial instability. They will need to be collectively owned, democratically controlled businesses, with a mission to anchor jobs, offer health insurance and pension funds, and a degree of dignity (Scholz 2014).
}

There is no single blueprint for the ideal platform co-op. Each attempt can be assessed by how far it departs from the extractive and dominance-ridden model. In order to understand what the endpoint is - the utopian goal that digital solidarity economy should strive for the key values should be identified.

According to Michel Bauwens, these aspects are three: sustainability, openness and solidarity (Bauwens 2016). The co-creation of the commons should be overseen by open, participatory governance models that include all stakeholders. Long-term sustainability - 
both internal, that is, arising from an equal distribution of power and remuneration, and external, that is, in relation with the environment - could also distinguish platform co-ops as being more resistant and rooted in their respective communities, in stark contrast to the disruptive, yet often short-lived conquest of cognitive and netarchical attempts to install new tools of value capture. Finally, even though many platform cooperatives produce and exist locally, their mechanisms should be open to upscaling (platform as a Creative Commons, as it were) and globally networked with other, similar pockets of resistance against cognitive capitalism.

There are a couple of different approaches to platform cooperativism the diverge on the issue of who exactly should be in control. Although it is widely agreed that workers themselves should participate to the fullest extent, the question is whether other stakeholders, including potential capital investors, governments, or for-profit backers should have equivalent governance rights. Some platforms may operate in a strictly non-profit manner to provide basic services to the community, yet legally function as municipal, publicly owned companies. Scholz introduces a typology of platform cooperatives, according to which different platform co-ops are distinguished by their specific ownership models:

1) cooperatively owned, online labor brokerages and market places, which belong to their workers, freelancers, or online shop owners, of which Loconomics freelancer co-op and Fairmondo decentralized e-commerce platform are highly successful examples;

2) city-owned platform cooperatives, which might be based on municipal utilities providers or used to pool local resources, such as rental spaces or shared transportation - there the Sharing Cities Alliance initiatives have paved the way for new urban co-ops to emerge;

3) producer-owned $^{2}$ platforms, which cater to the specific needs of groups that are both "produsers" and consumers of the content, such as music streaming platform Resonate, or artist-owned Stocksy for stock photography, both of which utilize mechanisms combining the dual nature of their userbase;

4) union-backed labor platforms, which build on the organizing power, resources, and know-how of occupational unions. The US taxi sector provides us with many local examples proving that unions are capable of launching technological offensives as well (Scholz 2016).

\footnotetext{
2 "Produser" is a portmanteau phrase combining "producer" and "user" to denote the two groups overlapping.
} 
Platform co-ops are emerging as the great new chapter of the old collective organization and egalitarian ownership story, since they are able to address issues of democratic governance, equitable income distribution, sustainability, and transparency. The technologies they are built on can indeed be cloned from the corporate platforms built on the premises of cognitive capitalism or netarchist rent-seeking at the network nodes. Most economists agree that worker cooperatives are in general more efficient than shareholder corporations, especially if the diversity of contributions across workers is low, external competitive pressure diminishes, and investments stagnate, something that is often due to low labor costs as well. The taxi sector might be a prime example - as the provision of car rides is rather uniform and competition is restricted by pure logistics, each local market is contestable once a platform co-op obtains the proper digital technology and funding to get traction.

Not all platforms are born equal, however. Which ownership and decision-making model is optimal for a given platform co-op? How are we to mitigate all the downsides of corporate platforms and not only envision but actually build a better working world with digital commons that are globally scalable while retaining their beneficial nature? How are we even to get real people, embedded in the current system, on the side of platform cooperatives?

\section{Next steps for the development of a viable alternative}

The challenge of facing cognitive capitalism and its newest form of netarchical platforms is not only a problem of mobilizing people around some technological tools. It is about redesigning them so that they offer realistically better working conditions, better user experience, and so that they value engagement in governance processes. It is essential, therefore, to focus on assessing the different models from a systemic perspective, on developing platforms as ecosystems of mechanisms, on algorithms, and on rules that uphold all the values cherished by cooperatives.

Building on Juliet Schor's observations that many idealistic, yet abstract projects lack clear value proposition that would attract larger communities, Trebor Scholz has proposed ten principles for platform co-ops when addressing the major problems in the cognitive capitalism regime of accumulation. Those ten principles of the early platform cooperativism debate are: 

1) ownership;
2) decent pay and income security;
3) transparency and data portability;
4) appreciation and acknowledgment;
5) co-determined work;
6) a protective legal framework;
7) portable worker protections and benefits;
8) protection against arbitrary behavior;
9) the rejection of excessive workplace surveillance;
10) and the right to log off (Scholz 2016).

Marina Gorbis of the Institute for the Future argues for a different set of rules, some of which overlap with Scholz's, whilst including others identified in the process of conducting research on gig economy workers. Her set of rules are based on her subjective experiences, yet show how Scholz's list omits some significant aspects:

1) earnings maximization;

2) stability and predictability;

3) transparency - both on the algorithmic and data levels;

4) the portability of products and reputations;

5) upskilling - meaning acquiring new skills and creating pathways for advancement;

6) social connectedness - overcoming the barrier of atomized, individual work;

7) bias elimination;

8) and feedback mechanisms (Gorbis 2017).

It is clear that what the workers themselves are expressing here are need for creating communities and connecting outside strictly job-related communications. This sense of cohesion also fosters labor rights advocacy. Another notable feature is upskilling, which proves that lifelong learning is not only a slogan of cognitive capitalism-era slogan, but for many people is desirable as a way to develop careers and improve living standards.

Discussing bias elimination is especially problematic if an attempt is made to confront the reality of today's platforms. Juliet Schor's studies of platforms that are volunteer-run and have features of cooperatives have led to quite disturbing findings. Status-seeking, less visible, subtle forms of social-exclusion, and other non-egalitarian behaviors have persisted in them, while gender, racial, and class inequalities are highly pervasive, if not threatening to their very viability (Schor 2017). High cultural capital was often a prerequisite of even finding and joining such a platform. Thus, an awareness of social 
dynamics are required, not to mention decisive steps to combat the influence of socially dominant groups, if platform co-ops are to function in broader society. The active involvement of new social groups, right from the outset, should also be encouraged.

It is also extremely important to remember that mono-stakeholder platforms are still capable of exploitation and value capture. Given a position of market dominance, cooperatives can always depart from valuing external sustainability designed to favor maximizing workers' profits, and thus become netarchical extractionary apparatuses but ones that are also great workplaces. This is the key reason why multi-stakeholder co-ops should be considered, with different classes of shares reserved for different groups. Michel Bauwens proposes that founders could be rewarded with shares that diminish over time, preventing them from turning into a life-long rent; furthermore, a similar scheme would apply to ethical investors who are willing to take the risk and support the initiative (Bauwens 2016). Other mechanisms would be dedicated to workers, users, and other stakeholders (local residents, etc.). Such a proposal recognizes the co-creative norm of modern cognitive capitalism. In this vein, the best practices of Somerset Rules are often mentioned: launched in the UK in 2009, they are written in plain English and combine many tested multi-stakeholder co-op models into a single, ready-to-use framework (Somerset Co-operative Services 2014).

A reflection on strategies of building up reveals that one way would be to create a new platform, although securing financing and having a strong core team with business skills strong enough to compete with incumbents might be a stretch too far. That is why cooperative financing and crowdfunding are extremely important. Still, in many cases an attempt can be made to render cognitive capitalism more humane. Or, in Brendan Martin's words, to convert it (Martin 2017). The goal is not to build a Facebook 2.0, but, if possible, to change its model. As many netarchical platforms have become global public utilities and attracted the attention of policymakers and critical thinkers alike, operating a platform might make it easier to put serious pressure on these groups - and should this fail, then the given platform ought to probably be abandoned.

Finally, platform co-ops are too frequently launched either in the startup model, or as a byproduct of short-lived activism. What is needed, however, is to convince unions that investment in digital platforms and promoting them amongst union members is potentially highly beneficial in the long-term. An experiment with new public services is needed at the municipal level, including the open crowdsourcing of urban development issues and complex real-estate platforms that would include short-time rentals (Airbnb style) as well as long-term ones, property rights, taxes, and even algorithms able to drive margins down by aiding a city's residents to counter real-estate owners and speculators. What is needed are state-backed or other publicly funded incubators and digital programs aimed at seeking the best solutions to communicate, freelance, trade, and innovate on the foundation of the 
digital commons. In his latest book, Scholz proposes that we view platform co-ops as part of the broader cooperative ecosystem, and thus turns our attention towards funding schemes, alliance-building, legal and engineering staffing, and software standards as well (Scholz 2017). His remarks on the seductive UX design again amplify the argument about the need to learn from startups and corporate "death stars" in order to effectively build them better. All those undertakings would greatly support the existing plethora of collectives that often lack the scale to burgeon properly, or even to utilize platform cooperativism to its maximum capacity.

\section{Conclusions}

As cognitive capitalism has matured, the fight for dominance over the value chain is coming to an end. Netarchists, by controlling key sharing economy platforms, marketplaces, and social media, will stay on top by extracting value directly from data flows. The new rentiers have come and hitherto they reign unobstructed, even as the deficiencies of their business models can be easily observed and described in detail.

Platform cooperatives seem the most promising of the possible answers. They make a bold statement by combining long-standing traditions with the most recent technology. An egalitarian, democratic, and peer-to-peer world needs its own infrastructure - and digital co-ops are the way to go. This answer may not be the perfect and final one, as some questions will still linger. Is it possible for a digital cooperative to reach the scale required to undertake massive investments and possibly lead to another breakthrough in technology that would enable it to stay ahead of the cognitive capitalist competition?

It is worth noting that platform co-ops need not necessarily be a perfect solution. If they prove better than cognitive capitalism apparatuses, they will undoubtedly serve their purpose. Nathan Schneider recounts his talks with Amazon Mechanical Turk workers at the Digital Labor conference, where they shared their many stories of abuse on the platform. But connecting also allowed for empowerment, even if brief:

Over the course of those days, a kind of question kept coming up among the Turkers, a thought experiment. They wondered aloud: What if we owned the platform? How would we set the rules?

They'd sit with that for a minute or two, batting ideas back and forth about how to make the platform better for themselves - and for Amazon. Reasonable ideas. Clever 
ones. But then ideas would fade back into reality again: back to the complaints (Schneider 2017).

Could this community become resilient and organized enough to create an alternative? Such a notion might be doubted. The financial capital roaming around the cognitive capitalist regime has the resources to combat all resistance, and buy the latest technology to always remain competitive. The netarchist class is already reinforcing its position in some markets, while in others there is still more hope. The only keys that they lack are: the real appreciation of users, who are now awakening to new possibilities and the benefits that collective, egalitarian, and open processes may provide given time. It remains unclear however, if these are enough for the commons paradigm to thrive in the digital era. 


\section{References}

Bauwens, Michael. 2016. "Michel Bauwens view on Platform Cooperativism: What it is \& why it matters." In Platform Cooperativism: an international movement on the rise. Eds. T. Dönnebrink and E. Kagel. http://www.supermarkt-berlin.net/wpcontent/uploads/2016/04/platformcoopberlin1 report-1604140849511.pdf (accessed on July 23, 2018).

Bratton, Benjamin H. 2016. The Stack: On Software and Sovereignty. Cambridge: The MIT Press. Brouillette, Sarah. 2009. "Creative Labor." Mediations. Journal of the Marxist Literary Group 24 (2).

Cillario, Lorenzo. 1990. "Il capitalismo cognitivo: Saper, sfruttamento e accumulazione dopo la rivoluzione informatica." In Transformazione e persistenza. Saggi sulla storicità. Eds. L. Cillario, R. Finelli, A. Illuminati, G. La Grassa, C. Preve. Milan: FrancoAngeli.

Cillario, Lorenzo. 1991. "Nel tempo del »capitalismo cognitivo«." Critica marxista 4-5.

Crawford, Kate, and Jason Schultz. 2014. "Big Data and Due Process: Toward a Framework to Redress Predictive Privacy Harms.” Boston College Law Review 55: 93-128.

Doligalski, Tymoteusz. 2013. "Platformy wielostronne: istota i rozwój relacji z klientami." Ementor 48.

Edelman, Benjamin, Michael Luca, and Dan Svirsky. 2017. "Racial Discrimination in the Sharing Economy: Evidence from a Field Experiment.” American Economic Journal: Applied Economics 9 (2): 1-22.

Ezrachi, Ariel, and Maurice E. Stucke. 2016. Virtual Competition: The Promise and Perils of the Algorithm-Driven Economy. Cambridge: Harvard University Press.

Fisher, Eran. 2010. "Contemporary Technology Discourse and the Legitimation of Capitalism.” European Journal of Social Theory 13 (2): 229-252.

Fuchs, Christian. 2013. Social Media: A Critical Introduction. 2nd ed. London: SAGE Publications.

Fumagalli, Andrea, and Stefano Lucarelli. 2007. "A Model of Cognitive Capitalism: A Preliminary Analysis." European Journal of Economic and Social Systems 20 (1): 117-133.

Gorbis, Marina. 2017. "Designing Positive Platforms." In Ours to Hack and to Own: The Rise of Platform Cooperativism, a New V ision for the Future of Work and A Fairer Internet. Eds. T. Scholz and N. Schneider. New York-London: OR Books.

Hannák, Anikó, Claudia Wagner, David Garcia, Alan Mislove, Markus Strohmaier, and Christo Wilson. 2017. "Bias in Online Freelance Marketplaces: Evidence from TaskRabbit and Fiverr." In CSCW'17 Proceedings of the 2017 ACM Conference on Computer Supported Cooperative Work and Social Computing. Eds. C.P. Lee, S. Poltrock, L. Barkhuus, M. Borges, and W. Kellogg. Portland: ACM.

Harvey, David. 2005. The New Imperialism, Oxford: Oxford University Press.

Hutchinson, Robert. 2008. "Knowledge and Control: A Marxian Perspective on the Productivity Paradox of Information Technology." Rethinking Marxism 20 (2): 288-304.

Huws, Ursula. 1999. "Material World: The Myth of the Weightless Economy." Socialist Register 35: 29-55.

International Telecommunication Union. 2017. ICT Facts and Figures 2017. Geneva: ITU.

Katz, Michael L., and Carl Shapiro. 1985. "Network externalities, competition and compatibility." American Economic Review 75: 424-440.

Kostakis, Vasilis, and Michael Bauwens. 2014. Network Society and Future Scenarios for a Collaborative Economy. London: Palgrave Macmillan UK. 
Kowalik, Zuzanna. 2017. "Gig economy a prawa pracownicze i sposoby organizacji pracowników." In \#FutureInsights: Technologie 4.0 a przemiany społeczno-gospodarcze. Eds. K. Kozłowski, and J.J. Zygmuntowski. Warszawa: Oficyna Wydawnicza SGH.

Langley, Paul, and Andrew Leyshon. 2017. "Platform capitalism: The intermediation and capitalisation of digital economic circulation." Finance and society 3 (1): 1-21.

Lazzarato, Maurizio, and Antonio Negri. 1991. "Travail immatériel et subjectivité." Futur Antérieur 6: 86-89.

Lee, Dayne. 2016. "How Airbnb Short-Term Rentals Exacerbate Los Angeles's Affordable Housing Crisis: Analysis and Policy Recommendations." Harvard Law \& Policy Review 10: 11-42.

Li, Shengli, Yipeng Liu, and Subhajyoti Bandyopadhyay. 2010. "Network effects in online two-sided market platforms: a research note." Decision Support Systems 49 (2): 245-249.

Martin, Brendan. 2017. "Money Is the Root of All Platforms." In Ours to Hack and to Own: The Rise of Platform Cooperativism, a New Vision for the Future of Work and A Fairer Internet. Eds. T. Scholz, and N. Schneider. New York-London: OR Books.

Mikołajewska-Zając, Karolina, and Olga Rodak. 2016. "Platformy spółdzielcze jako próba rewizji korporacyjnego modelu gospodarki współdzielonej." E-mentor 66.

O’Dwyer, Rachel. 2015. "Money Talks: The Enclosure of Mobile Payments." In MoneyLab Reader: An Intervention in Digital Economy. Eds. G. Lovink, N. Tkacz, and P. de Vries. Amsterdam: Institute of Network Cultures.

O’Neil, Cathy. 2016. Weapons of Math Destruction: How Big Data Increases Inequality and Threatens Democracy. Danvers: Crown Publishing.

Pasquale, Frank. 2016. The Black Box Society: The Secret Algorithms That Control Money and Information. Cambridge: Harvard University Press.

Polanyi, Karl. 1944. The Great Transformation: The Political and Economic Origins of Our Time. Boston: Beacon Press [2nd edition; 2001].

Ratajczak, Mikołaj. 2015. “Wprowadzenie do teorii kapitalizmu kognitywnego: kapitalizm kognitywny jako reżim akumulacji." Praktyka Teoretyczna 1 (15): 57-94.

Rifkin, Jeremy. 2001. The Age of Access: The New Culture of Hypercapitalism, Where all of Life is a Paid-For Experience. New York: TarcherPerigee.

Schneider, Nathan. 2017. "The Meanings of Words." In Ours to Hack and to Own: The Rise of Platform Cooperativism, a New Vision for the Future of Work and A Fairer Internet. Eds. T. Scholz, and N. Schneider. New York-London: OR Books.

Scholz, Trebor. 2016. "Platform Cooperativism vs. the Sharing Economy." https://medium.com/@trebors/platform-cooperativism-vs-the-sharing-economy2ea737f1b5ad (accessed on July 23, 2018).

Scholz, Trebor. 2016. Platform Cooperativism: Challenging the Corporate Sharing Economy. New York: Rosa Luxemburg Stiftung.

Scholz, Trebor. 2017. Uberworked and Underpaid: How Workers Are Disrupting the Digital Economy. Cambridge: Polity Press.

Schor, Juliet B. 2017. "Old Exclusion in Emergent Spaces." In Ours to Hack and to Own: The Rise of Platform Cooperativism, a New Vision for the Future of Work and A Fairer Internet, ed. by Trebor Scholz and Nathan Schneider. New York-London: OR Books.

Selten, Reinhard. 1968. An Oligopoly Model with Demand Inertia. University of California.

Somerset Co-operative Services. 2014. Somerset Rules 2014 Multistakeholder Co-operative. http://www.somerset.coop/p/somerset-rules-registrations.html (accessed on July 23, 2018).

Srnicek, Nick. 2016. Platform Capitalism. Cambridge: Polity Press. 
Vercellone, Carlo. 2007. "From Formal Subsumption to General Intellect: Elements for a Marxist Reading of the Thesis of Cognitive Capitalism." Historical Materialism 15: 13-36. Wark, McKenzie. 2004. A Hacker Manifesto. Cambridge: Harvard University Press.

Zygmuntowski, Jan J. 2017. "Rewolucja platform wielostronnych. Refleksja nad gospodarką współdzielenia w świetle interesu publicznego.” In \#FutureInsights: Technologie 4.0 a przemiany społeczno-gospodarcze. Eds. K. Kozłowski, and J.J. Zygmuntowski. Warszawa: Oficyna Wydawnicza

SGH. 
Jan J. Zygmuntowski - is an economist specializing in the fields of innovation, automation and digital business. He serves as President of the Board at Instrat Foundation and works at Polish strategic institution for growth financing. He co-redacted the book \#FutureInsights: Technologie 4.0 a przemiany społeczno-gospodarcze (“\#FutureInsights: 4.0 technologies and socio-economic transformation"; Oficyna Wydawnicza SGH 2017). Alumni of the Warsaw School of Economics, fellow of the G20 Global Solutions in 2017.

\section{ADDRESS:}

Jan J. Zygmuntowski

Fundacja Instrat

ul. Wołowska $70 / 48$

02-507 Warsaw

E-MAIL: jan.zygmuntowski@instrat.pl

CITATION: Zygmuntowski, Jan J. 2018. "Commoning in the Digital Era: Platform Cooperativism as a Counter to Cognitive Capitalism.” Praktyka Teoretyczna 1(27): 168-192.

DOI: $10.14746 /$ prt.2018.1.7

Jan J. Zygmuntowski - ekonomista zawodowo i badawczo związany z obszarami innowacji, automatyzacji pracy i cyfrowej gospodarki. Prezes Zarządu Fundacji Instrat oraz pracownik strategicznej instytucji finansowania rozwoju. Współredaktor monografii naukowej \#FutureInsights: Technologie 4.0 a przemiany społeczno-gospodarcze (Oficyna Wydawnicza SGH 2017). Absolwent Szkoły Głównej Handlowej w Warszawie, stypendysta G20 Global Solutions (2017).

TYTUL: Commoning w erze cyfrowej: platformowy kooperatyzm jako odpowiedź na kapitalizm kognitywny

ABSTRAKT: Wraz z rozpowszechnieniem technologii ICT wyłoniły się modele organizacji ekonomicznej takie jak platformy, media społecznościowe oraz firmy gospodarki współdzielenia (sharing economy). Autor artykułu analizuje ich funkcjonowanie na poziomie mikro- i dostarcza szeregu argumentów krytycznych. Eksploracja teorii kapitalizmu kognitywnego i stanowisk ustosunkowanych wobec niej polemicznie pozwala na uzyskanie holistycznego obrazu sytuacji oraz na obserwację tego, jak wartość jest przechwytywana i akumulowana przy użyciu aparatów technologicznych. Kapitalizm kognitywny nie jest jednak jednorodny, a dostrzeżenie szczególnych właściwości cechujących sieci pozwala zidentyfikować wyzwanie rzucone nam przez rosnącą liczbę netarchicznych platform. Platformowy kooperatyzm jest ujmowany jako egalitarna i zrównoważona w długim okresie 
odpowiedź na te zjawiska, gdyż celem tej idei jest projektowanie nowych narzędzi funkcjonujących w zgodzie $\mathrm{z}$ paradygmatem dobra wspólnego (the commons). Wreszcie w artykule wskazane zostały kluczowe detale, trudności i następne kroki prowadzące do tworzenia lepszych platformowych kooperatyw i lepszej przyszłości.

SLOWA KLUCZOWE: platformowy kooperatyzm, kapitalizm kognitywny, gospodarka współdzielenia, wartość, cyfrowe dobra wspólne. 